\title{
Association of FcyRlla R131H polymorphism with idiopathic pulmonary fibrosis severity and progression
}

\author{
Stylianos Bournazos ${ }^{1,2}$, Jacob Grinfeld ${ }^{1}$, Karen M Alexander ${ }^{1}$, John T Murchison ${ }^{3}$, William A Wallace ${ }^{1,4}$, \\ Pauline McFarlane ${ }^{5}$, Nikhil Hirani ${ }^{1,5}$, A John Simpson ${ }^{1,5}$, lan Dransfield ${ }^{1}$, Simon P Hart ${ }^{6^{*}}$
}

\begin{abstract}
Background: A significant genetic component has been described for idiopathic pulmonary fibrosis (IPF). The $\mathrm{R} 131 \mathrm{H}$ (rs1801274) polymorphism of the IgG receptor FcyRlla determines receptor affinity for IgG subclasses and is associated with several chronic inflammatory diseases. We investigated whether this polymorphism is associated with IPF susceptibility or progression.
\end{abstract}

Methods: In a case-control study, we compared the distribution of FcyRlla R131H genotypes in 142 patients with IPF and in 218 controls using allele-specific PCR amplification.

Results: No differences in the frequency of FcyRlla genotypes were evident between IPF patients and control subjects. However, significantly impaired pulmonary function at diagnosis was observed in $\mathrm{HH}$ compared to RR homozygotes, with evidence of more severe restriction (reduced forced vital capacity (FVC)) and lower diffusing capacity for carbon monoxide $\left(\mathrm{DL}_{\mathrm{co}}\right)$. Similarly, increased frequency of the $\mathrm{H} 131$ allele was observed in patients with severe disease $\left(\mathrm{DL}_{\mathrm{CO}}<40 \%\right.$ predicted) ( 0.53 vs. $0.38 ; \mathrm{p}=0.03$ ). Furthermore, the H131 allele was associated with progressive pulmonary fibrosis as determined by $>10 \%$ drop in $\mathrm{FVC}$ and/or $>15 \%$ fall in $\mathrm{DL}_{\mathrm{CO}}$ at 12 months after baseline (0.48 vs. 0.33; $p=0.023$ ).

Conclusions: These findings support an association between the FcyRlla R131H polymorphism and IPF severity and progression, supporting the involvement of immunological mechanisms in IPF pathogenesis.

\section{Background}

Idiopathic pulmonary fibrosis (IPF) is a non-neoplastic lung disease of unknown etiology and represents the most common clinical entity within the group of idiopathic interstitial pneumonias. The histological correlate of IPF is usual interstitial pneumonia (UIP), in which areas of interstitial fibrosis of various ages are interspersed with normal lung [1,2]. This histological pattern could be explained by repeated episodes of lung injury separated in time and place followed by an uncontrolled wound healing response that consequently leads to excessive fibrosis. Although for some fibrosing interstitial lung diseases the initiating lung injury is well defined and might include inhaled allergens,

\footnotetext{
* Correspondence: s.hart@hull.ac.uk

${ }^{6}$ Division of Cardiovascular and Respiratory Studies, Hull York Medical

School/University of Hull, Castle Hill Hospital, Cottingham, UK

Full list of author information is available at the end of the article
}

dust, or fibers [2], in IPF the cause of the initiating lung injury has not been identified. However, several lines of evidence support a role for immune complexes (antibodyantigen complexes) as mediators of lung injury in IPF that ultimately elicit a pro-fibrotic response [3]. Normally, immune complexes that are formed during an immune response are rapidly cleared by tissue-resident phagocytes. However, in many chronic inflammatory diseases elevated levels of circulating immune complexes as well as their deposition in tissues have been detected, which consequently promote tissue injury via activation of complement and engagement of leukocyte Fc receptors [4-6]. In the context of IPF, pulmonary fibrosis has been induced in animals following administration of immune complexes $[3,7]$. Secondly, lung fibrosis resembling IPF occurs in patients with autoimmune rheumatic diseases, including rheumatoid arthritis and scleroderma. Thirdly, immune 
complexes have been detected in the serum and the lung of patients with IPF [8-16].

IgG-containing immune complexes are recognized via Fc $\gamma$ receptors, which are expressed predominantly by leukocytes. Substantial genetic variation in the form of single nucleotide polymorphisms (SNPs) has been described for Fc $\gamma$ receptor genes, and their association with several chronic inflammatory and autoimmune diseases has been reported (reviewed in [17]). The R131H (rs1801274) substitution of Fc $\gamma$ RIIa, a low-affinity IgG receptor that is widely expressed by diverse leukocyte types, maps to the receptor interface interacting with the Fc region of IgG and determines the affinity of Fc $\gamma$ RIIa for human IgG subclasses [17]. The H131 but not the R131 variant is capable of interacting with IgG2 and has been previously shown to bind and mediate phagocytosis of IgG2-coated particles [18]. In the present study we investigated whether the Fc $\gamma$ RIIa R131H polymorphism is associated with IPF disease susceptibility or progression.

\section{Methods}

\section{Study Design and Subjects}

In this case-control study, 142 IPF patients and 218 controls were recruited and the Fc $\gamma$ RIIa R131H genotype was determined. For IPF patients, pulmonary function was assessed at baseline and repeated at intervals over 12 months to assess disease progression. IPF patients were categorized according to disease severity $\left(\mathrm{DL}_{\mathrm{CO}}<40 \%\right.$ predicted at presentation) and progression (reduction of $\geq 10 \%$ in FVC or $\geq 15 \%$ in $\mathrm{DL}_{\mathrm{CO}}$ in the first 12 months).

IPF $(n=142)$ was diagnosed in patients attending a specialist interstitial lung disease clinic according to the American Thoracic Society (ATS)/European Respiratory Society (ERS) international multidisciplinary consensus classification $[2,19]$. The baseline characteristics of the IPF cohort are summarized in Table 1. Bronchoalveolar lavage (BAL) and/or surgical lung biopsy were performed in cases for which a confident diagnosis on clinical, functional and radiological grounds was not possible. A consensus diagnosis was made in each case following joint review by two respiratory clinicians and a radiologist (and a pathologist for cases in which biopsy was performed). The control group $(n=218)$ comprised age-matched patients $(n=70)$ with a number of different acute or chronic lung pathologies other than an interstitial lung disease, ranging from asthma and seasonal influenza to pneumonia and lung cancer that were admitted to Edinburgh Royal Infirmary (mean age: $71.4 \pm 10.2$; female/ male: $34 / 36)$ and healthy blood donors $(n=148$; female/ male: $65 / 83$ ). No differences in the $\mathrm{R} 131 \mathrm{H}$ genotype frequencies were evident between the control patient and healthy donor subgroups so these two subgroups were combined. All subjects were Caucasians. Ethical approval
Table 1 Baseline Pulmonary Function of the IPF Cohort

\begin{tabular}{lc}
\hline Patients, $n$ & 142 \\
Age, $y$ (range) & $70 \pm 8.8(50-87)$ \\
Gender, F/M (\%) & $47 / 95(33.1 / 66.9)$ \\
& \\
FEV $_{\mathbf{1}}, \mathrm{L}$ & $2.16 \pm 0.6$ \\
$\%$ Predicted & $87.52 \pm 20.0$ \\
FVC, $L$ & $2.76 \pm 0.8$ \\
$\%$ Predicted & $87.65 \pm 19.6$ \\
FEV $\mathbf{1}$ /VC, \% predicted & $79.07 \pm 9.9$ \\
TLC, $L$ & $4.30 \pm 1.0$ \\
$\%$ Predicted & $74.20 \pm 15.3$ \\
DLco, $\mathrm{ml} / \mathrm{min} / \mathrm{mmHg}$ & $4.11 \pm 1.4$ \\
$\%$ Predicted & $52.75 \pm 15.9$ \\
$\mathbf{K}_{\mathbf{C O}}, \mathrm{ml} / \mathrm{min} / \mathrm{mmHg} / \mathrm{L}$ & $1.10 \pm 0.3$ \\
$\%$ Predicted & $82.47 \pm 22.8$ \\
\hline
\end{tabular}

Values as mean \pm SD. Abbreviations: IPF: idiopathic pulmonary fibrosis; $\mathrm{DL}_{\mathrm{CO}}$ : Diffusing capacity of the lung for carbon monoxide; $\mathrm{K}_{\mathrm{CO}}$ : $\mathrm{DL}_{\mathrm{co}}$ corrected for lung volume.

was obtained from the Lothian Research Ethics Committee (LREC/2002/4/65) and informed consent was obtained from all subjects.

Pulmonary function measurements were recorded at baseline (first radiologic evidence for IPF) and at 6 and 12 months ( \pm 1 month) following diagnosis to assess disease progression in 121 patients with IPF. The remaining 21 patients were lost to follow up or were unfit to perform serial testing.

\section{FcyRIla R131H Genotyping}

Genomic DNA was extracted from $2 \mathrm{ml}$ of peripheral venous blood using a QIAamp DNA Blood Midi Kit (Qiagen) following the manufacturer's instructions. For the determination of Fc $\gamma$ RIIa R131H genotypes, PCR amplification reactions were performed using allele-specific PCR primers (Eurofins, MWG). For the R131 allele: forward: 5'AAATCCCAGAAATTCTCACG, reverse: 5'-CACTCC TCTTTGCTCCAGTG; For the H131 allele: forward: 5'AAATCCCAGAAATTCTCACA, reverse: 5'-CACTCCT CTTTGCTCCAGTG. Primers were designed based on the human DNA reference sequence (NCBI build 36.1). Nucleotides in bold are allele-specific and those underlined indicate nucleotides deliberately mismatched to the original gene sequences to increase primer specificity. PCR amplification reactions were performed in $50 \mu \mathrm{l}$ volume, containing $200 \mu \mathrm{M}$ dNTP, $1.5 \mathrm{mM} \mathrm{MgCl}_{2}, 200 \mathrm{nM}$ of each primer pair (forward and reverse), $2.5 \mathrm{U}$ Taq DNA polymerase (GoTaq Flexi DNA Polymerase, Promega) in green $1 \times$ GoTaq Flexi buffer (Promega), and $1 \mu \mathrm{l}$ of extracted genomic DNA (200-500 ng). PCR amplification conditions were $5 \mathrm{~min}$ at $94^{\circ} \mathrm{C}$, followed by 30 cycles of 45 sec at $94^{\circ} \mathrm{C}, 45 \mathrm{sec}$ at $54^{\circ} \mathrm{C}$ and $45 \mathrm{sec}$ at $72^{\circ} \mathrm{C}$ and a final extension step of $5 \mathrm{~min}$ at $72^{\circ} \mathrm{C}$. PCR products (269 bp) 
were analysed by $2 \%(\mathrm{w} / \mathrm{v})$ agarose gel electrophoresis. The efficiency and specificity of the allele-specific PCR amplification was validated by direct sequencing using Applied Biosystems Big-Dye 3.1 chemistry on an Applied Biosystems model 3730 automated capillary DNA sequencer (College of Life Sciences, University of Dundee, UK). The number of samples analysed by direct sequencing corresponded to about $10 \%$ of the total analysed samples $(\mathrm{n}=$ 360 ) with a minimum of 10 for each tested genotype (RR, $\mathrm{RH}, \mathrm{HH})$. In all cases, the genotypes obtained from the sequencing-based method matched those obtained by PCR.

\section{Genetic and Statistical Analysis}

Hardy-Weinberg equilibrium was assessed by a $\chi^{2}$ test with one degree of freedom. Differences in the genotype and allele frequencies between control and IPF patients were analysed by the $\chi^{2}$ or Fisher's exact tests. The statistical power $(\alpha=0.05)$ of this study to detect differences in the minor (H131) allele frequency corresponding to odds ratio (OR) of 2 between control and IPF groups reached $98.8 \%$. One-way analysis of variance (ANOVA) was used to test for differences in the mean values of quantitative variables, and where statistically significant effects were found post-hoc analysis using the Bonferroni test was performed. Unless otherwise stated, quantitative data are presented as mean $\pm \mathrm{SD}$ and $\mathrm{p}<0.05$ was considered to be statistically significant. Data were analysed with GraphPad Prism software (Graphpad) and statistical power was calculated using the GraphPad StatMate software (Graphpad).

\section{Results \\ FcyRlla R131H polymorphism does not confer susceptibility to IPF}

Both in the control and in the IPF cohort there was agreement between genotypes observed and those predicted by the Hardy-Weinberg equilibrium (controls: $\chi^{2}=0.008, \mathrm{p}=$ 0.93 ; IPF: $\chi^{2}=1.83, \mathrm{p}=0.18$ ). No significant differences in the distribution and frequency of the Fc $\gamma$ RIIA R131H genotypes (RR, RH, HH) were observed between control subjects and IPF patients (RR: 0.36 for control vs. 0.37 for IPF; $\mathrm{RH}: 0.48$ vs. $0.43 ; \mathrm{HH}: 0.16$ vs. $0.20 ; \chi^{2}=1.38, d f 2, \mathrm{p}=$ $0.50)$. Allelic frequency of R131 and H131 variants in IPF patients was comparable to those noted for the control group (R: control vs. IPF, 0.60 vs. 0.59 ; $\mathrm{H}$ : 0.40 vs. 0.41 ; $\mathrm{p}=0.70$, OR 1.07, 95\% CI 0.79-1.44).

These data suggest there is no difference in the frequency of the FcrRIIa R131 polymorphism between control and IPF groups.

\section{The FcyRlla H131 variant is associated with more severe} disease at presentation

We next compared the $\mathrm{R} 131 \mathrm{H}$ genotype frequencies with pulmonary function measurements obtained at presentation. Homozygous carriers of the $\mathrm{H}$ allele had significantly lower FEV1 and FVC compared with RR homozygotes (Table 2; Figure 1A-B). In addition, substantially impaired pulmonary gas transfer was observed in H131 homozygous patients, as evidenced by significantly reduced levels of $\mathrm{DL}_{\mathrm{CO}}$ in these patients compared to RR homozygotes (Figure $1 \mathrm{C}$ ). $\mathrm{DL}_{\mathrm{CO}}$ is a reliable guide to outcome and values of less than $40 \%$ of predicted are generally indicative of advanced disease [2]. Significantly increased frequencies of the $\mathrm{HH}$ and $\mathrm{RH}$ genotypes were evident in the IPF subgroup with $\mathrm{DL}_{\mathrm{CO}}<40 \%$ vs. those with $\mathrm{DL}_{\mathrm{CO}} \geq 40 \%\left(<40 \% \mathrm{DL}_{\mathrm{CO}}\right.$ $\mathrm{HH}: 0.25, \mathrm{RH}: 0.56, \mathrm{RR}: 0.19 ; \geq 40 \% \mathrm{DL}_{\mathrm{CO}} \mathrm{HH}: 0.18, \mathrm{RH}$ : 0.39 , RR: $\left.0.43 ; \chi^{2} 6.1, d f 2, \mathrm{p}=0.04\right)$. In addition, the overall frequency of the $\mathrm{H}$ allele was increased in patients with $\mathrm{DL}_{\mathrm{CO}}<40 \%$ compared to those with $\mathrm{DL}_{\mathrm{CO}} \geq 40 \%$ predicted ( 0.53 vs. $0.38 ; \mathrm{p}=0.03$, OR 1.87 , 95\% CI 1.07-3.28). Homozygotes and heterozygotes of the $\mathrm{H}$ allele were associated with $\mathrm{DL}_{\mathrm{CO}}<40 \%$ predicted ( $\mathrm{p}=0.01$, OR $3.23,95 \%$ CI 1.23-8.49). Collectively, these results indicate that the $\mathrm{H}$ allele is associated with reduced pulmonary function at presentation in IPF, which is indicative of more advanced disease.

\section{$\mathrm{R} 131 \mathrm{H}$ polymorphism is associated with IPF disease progression}

To further investigate IPF disease progression, serial lung function measurements for the first 12 months following baseline were obtained and the percent change in FVC and $\mathrm{DL}_{\mathrm{CO}}$ were determined.

A drop from baseline of $\geq 10 \%$ in FVC or $\geq 15 \%$ in $\mathrm{DL}_{\mathrm{CO}}$ in the first 6-12 months is associated with higher

Table 2 Baseline Pulmonary Function of IPF Patients According to FcyRlla Genotypes

\begin{tabular}{|c|c|c|c|c|}
\hline & & YRIla Genoty & & \\
\hline & RR & $\mathrm{RH}$ & $\mathrm{HH}$ & $P$ value \\
\hline Patients, $n$ & 53 & 61 & 28 & \\
\hline Age, y & $70.1 \pm 8.9$ & $70.1 \pm 8.9$ & $69.8 \pm 10.5$ & NS \\
\hline $\mathrm{FEV}_{1}, L$ & $2.31 \pm 0.6$ & $2.12 \pm 0.6$ & $1.96 \pm 0.5$ & 0.037 \\
\hline$\%$ predicted & $93.0 \pm 22.0$ & $85.7 \pm 17.4$ & $81.5 \pm 19.4$ & 0.031 \\
\hline FVC, $L$ & $2.92 \pm 0.8$ & $2.75 \pm 0.8$ & $2.43 \pm 0.6$ & 0.026 \\
\hline$\%$ predicted & $91.9 \pm 20.6$ & $87.1 \pm 17.4$ & $80.1 \pm 20.7$ & 0.041 \\
\hline $\mathbf{F E V}_{\mathbf{1}} / \mathbf{V C}, \%$ predicted & $79.7 \pm 9.4$ & $77.5 \pm 10.2$ & $81.3 \pm 9.7$ & NS \\
\hline TLC, $L$ & $4.47 \pm 0.9$ & $4.82 \pm 1.1$ & $3.94 \pm 1.0$ & NS \\
\hline$\%$ predicted & $76.7 \pm 14.0$ & $72.9 \pm 15.8$ & $71.8 \pm 16.5$ & NS \\
\hline $\mathbf{D L}_{\mathrm{co}}, \mathrm{ml} / \mathrm{min} / \mathrm{mmHg}$ & $4.49 \pm 1.4$ & $3.98 \pm 1.2$ & $3.54 \pm 1.4$ & 0.012 \\
\hline$\%$ predicted & $57.4 \pm 15.4$ & $51.4 \pm 15.0$ & $45.7 \pm 16.4$ & 0.007 \\
\hline $\mathbf{K}_{\mathbf{C O}}, \mathrm{ml} / \mathrm{min} / \mathrm{mmHg} / \mathrm{L}$ & $1.17 \pm 0.3$ & $1.07 \pm 0.3$ & $1.06 \pm 0.3$ & NS \\
\hline$\%$ predicted & $87.6 \pm 24.6$ & $80.1 \pm 20.5$ & $76.6 \pm 22.9$ & NS \\
\hline
\end{tabular}

Values as mean $\pm S D$. $P$ values $(P)$ for RR vs. $H H$ comparison. Abbreviations: NS: non-significant; IPF: idiopathic pulmonary fibrosis; $\mathrm{DL}_{\mathrm{CO}}$ : Diffusing capacity of the lung for carbon monoxide; $\mathrm{K}_{\mathrm{CO}}$ : $\mathrm{DL}_{\mathrm{CO}}$ corrected for lung volume. 
A

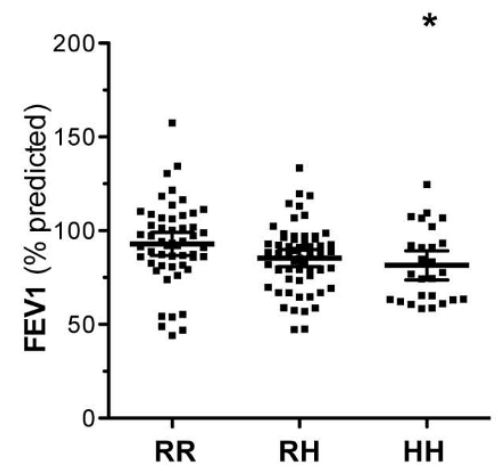

B

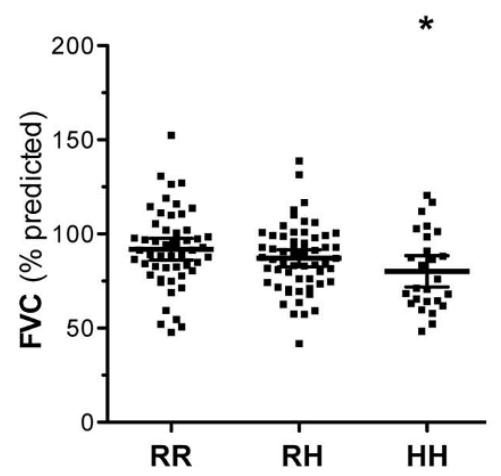

C

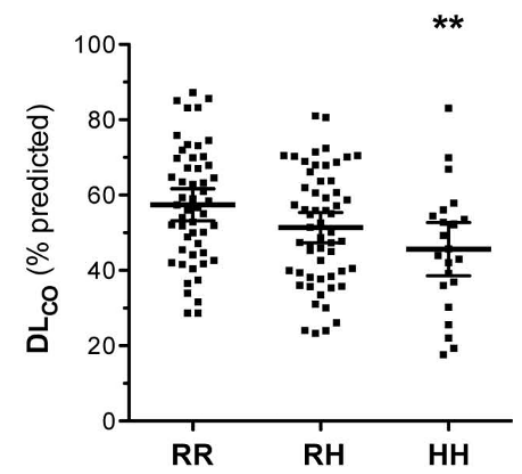

Figure 1 H131 variant is associated with impaired pulmonary function at baseline. (A) FEV1 (forced expiratory volume in 1 second), (B) FVC (forced vital capacity), and (C) DL (diffusing capacity of the lung for carbon monoxide) were determined in IPF patients and their association with FcyRlla R131H genotypes was assessed. Data are presented as the mean percent predicted value $\pm 95 \%$ confidence intervals (Cl). ${ }^{*} \mathrm{p}<0.05$ RR vs. HH, ${ }^{* *} \mathrm{p}<0.01$ RR vs. HH.

mortality and with a more aggressive form of IPF [2,20-22]. Therefore, patients were categorized into either progressive $(n=49)$ or non-progressive $(n=72)$ groups and their association with the Fc $\gamma$ RIIa R131H genotypes was investigated. Significant skewing in the distribution of the $\mathrm{R} 131 \mathrm{H}$ genotypes ( $\mathrm{RR}, \mathrm{RH}$, and $\mathrm{HH}$ ) was noted between progressive and non-progressive groups (Table 3). In particular, in the progressive group there was higher frequency of the HH genotype (0.29 vs. $0.11)$ as well as decreased RR genotype frequency ( 0.33 vs. $\left.0.44 ; \chi^{2}=6.13, d f 2, \mathrm{p}=0.047\right)$ compared to the nonprogressive group. In addition, the frequency of the $\mathrm{H}$ allele was increased in the progressive group compared to the non-progressive group (0.48 vs. $0.33 ; \mathrm{p}=0.023$, OR $1.84,95 \%$ CI 1.09-3.12).
Furthermore, a significant reduction in FVC was observed in the first 12 months in $\mathrm{HH}$ homozygotes, compared to homozygous and heterozygous carriers of the $\mathrm{R}$ allele (Figure 2). In contrast, no major change in $\mathrm{DL}_{\mathrm{CO}}$ was evident between the three $\mathrm{R} 131 \mathrm{H}$ genotypes, despite the lower baseline $\mathrm{DL}_{\mathrm{CO}}$ values observed in $\mathrm{HH}$ patients (data not shown). In summary, all these findings suggest that the Fc $\gamma$ RIIa R131H polymorphism represents a genetic risk factor for IPF disease progression.

\section{Discussion}

The current model of IPF pathogenesis suggests a dysregulated wound-healing response with minimal inflammation in response to alveolar epithelial damage. Although the cause of epithelial injury is unknown, immunological

Table 3 Genotype Frequencies and Pulmonary Function of Progressive and Non-progressive Subgroups of IPF Patients

\begin{tabular}{|c|c|c|c|}
\hline & & Progressive Group & Non-Progressive Group \\
\hline Patients, $n$ & & 49 & 72 \\
\hline Age, y (range) & & $70.51 \pm 9.3$ & $69.95 \pm 8.9$ \\
\hline Gender, F/M (\%) & & $12 / 37(24.5 / 75.5)$ & 26/46 (36.1/63.9) \\
\hline \multirow[t]{4}{*}{ FcyRlla Genotypes, n (\%) } & $\mathbf{R R}$ & $16(32.7)$ & $32(44.4)$ \\
\hline & $\mathrm{RH}$ & $19(38.8)$ & $32(44.4)$ \\
\hline & $\mathrm{HH}$ & $14(28.6)$ & $8(11.1)$ \\
\hline & & \multicolumn{2}{|c|}{$\chi^{2}=6.13, d f 2, p=0.047$} \\
\hline \multirow[t]{3}{*}{ FcyRlla Alleles, $n$ (\%) } & $\mathbf{R}$ & $51(52.0)$ & $96(66.7)$ \\
\hline & $\mathbf{H}$ & $47(48.0)$ & $48(33.3)$ \\
\hline & & \multicolumn{2}{|c|}{$p=0.023$, OR $1.84,95 \%$ Cl 1.09-3.12 } \\
\hline $\mathbf{F E V}_{\mathbf{1}}, L$ (\% predicted) & & $2.29 \pm 0.6(90.3 \pm 20.9)$ & $2.19 \pm 0.6(89.2 \pm 18.8)$ \\
\hline FVC, L (\% predicted) & & $2.81 \pm 0.7(86.8 \pm 21.1)$ & $2.86 \pm 0.8(91.7 \pm 17.8)$ \\
\hline $\mathbf{F E V}_{\mathbf{1}} / \mathbf{V C}, \%$ predicted & & $81.96 \pm 9.9$ & $77.05 \pm 9.5$ \\
\hline TLC, L (\% predicted) & & $4.33 \pm 1.0(71.5 \pm 15.6)$ & $4.43 \pm 1.0(76.8 \pm 13.5)$ \\
\hline $\mathrm{DL}_{\mathrm{co}}, \mathrm{ml} / \mathrm{min} / \mathrm{mmHg}$ (\% predicted) & & $4.13 \pm 1.3(52.2 \pm 16.3)$ & $4.18 \pm 1.3(53.8 \pm 14.3)$ \\
\hline $\mathbf{K}_{\mathrm{co}}, \mathrm{ml} / \mathrm{min} / \mathrm{mmHg} / \mathrm{L}$ (\% predicted) & & $1.08 \pm 0.3(82.7 \pm 22.8)$ & $1.10 \pm 0.3(81.7 \pm 22.8)$ \\
\hline
\end{tabular}

Disease progression groups were determined based on changes in FVC or DL Co. Progressive group displayed a $\geq 10 \%$ decrease in FVC and/or a $\geq 15 \%$ decrease in $\mathrm{DL}_{\mathrm{co}} 12$ months after baseline measurements. Values as mean \pm SD. Abbreviations: IPF: idiopathic pulmonary fibrosis; $\mathrm{DL}_{\mathrm{co}}$ : Diffusing capacity of the lung for carbon monoxide; $\mathrm{K}_{\mathrm{CO}}$ : $\mathrm{DL}_{\mathrm{CO}}$ corrected for lung volume. 


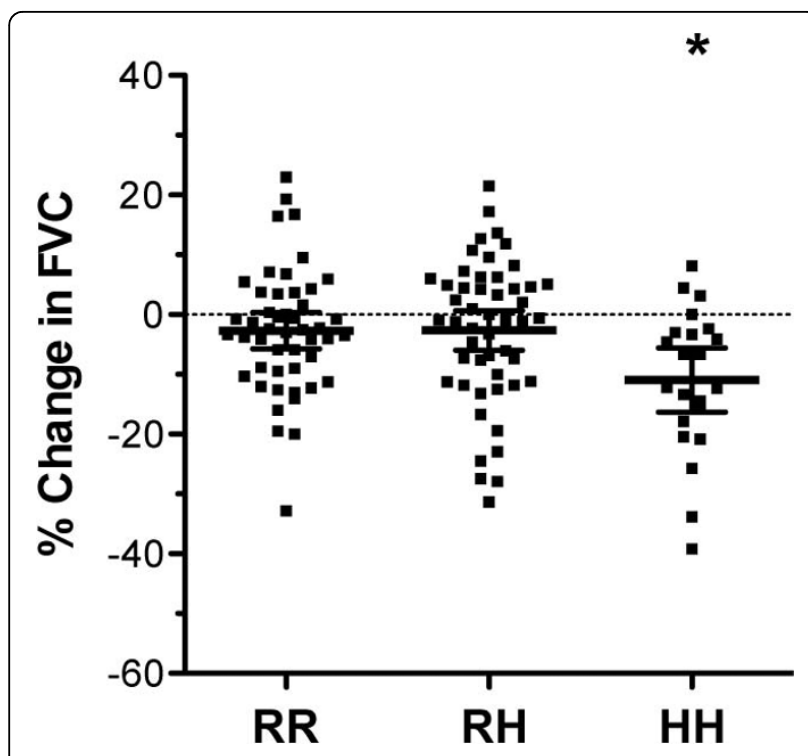

Figure $2 \mathrm{R} 131 \mathrm{H}$ polymorphism is associated with disease progression. Serial lung function measurements were obtained for 121 IPF patients 12 months following baseline to assess disease progression. FVC (forced vital capacity) displayed a significant fall in $\mathrm{HH}$, but not RR or RH patients. Data are presented as the mean percent change in actual values 12 months following baseline $\pm 95 \%$ confidence intervals (Cl). ${ }^{*} p<0.01$ RR vs. $\mathrm{HH}$.

determinants in IPF pathogenesis should be considered [23]. In the present study, we have demonstrated that the H131 variant of Fc $\gamma$ RIIa is associated with disease severity at presentation and progression over the subsequent 12 months. In particular, increased frequency of the H131 allele was observed in patients with more advanced disease ( $\mathrm{DL}_{\mathrm{CO}}<40 \%$ predicted). Similarly, $\mathrm{HH}$ homozygotes displayed significantly impaired baseline pulmonary function compared to RR homozygotes, with evidence of more severe restriction and reduction in gas transfer. In addition, significant association of this allele was evident in IPF patients with progressive disease ( $>10 \%$ drop in FVC and/or $>15 \%$ in $\mathrm{DL}_{\mathrm{CO}}$ ).

Our data also suggest that lung function is dependent on the number of $\mathrm{H}$ alleles. In particular, as illustrated in Figure $1 \mathrm{~A}-\mathrm{C}$ and Table 2, baseline pulmonary function seemed to correlate with $\mathrm{H}$ alleles frequency in each patient. For example, more severe restriction and impaired gas transfer was evident in $\mathrm{HH}$ homozygotes compared to $\mathrm{RH}$ heterozygotes, and accordingly, in $\mathrm{RH}$ heterozygotes compared to RR homozygotes. This observation suggests a dose-dependent effect for the $\mathrm{H}$ allele on pulmonary function and therefore in disease manifestation. Similarly, a dose response relationship has been previously demonstrated for the R131 allele and SLE [24]. Collectively, our findings suggest that the
$\mathrm{R} 131 \mathrm{H}$ polymorphism is an additional determinant that influences IPF severity and progression.

Previous studies on the Fc $\gamma$ RIIa R131H polymorphism have provided information about the functional consequences of this polymorphism. Association of the H131 variant has also been previously reported for a number of chronic inflammatory disorders, including periodontitis and Guillain-Barré syndrome [25-27], possibly due to the increased capacity of this variant for efficiently recognising IgG2. Since Fc $\gamma$ RIIa is expressed by diverse leukocyte types, including macrophages and neutrophils which are typically observed in the BAL fluid of IPF patients [2,17], the $\mathrm{R} 131 \mathrm{H}$ polymorphism is likely to influence IgGmediated effector responses in these cell types. Indeed, engagement of Fc $\gamma$ RIIa with IgG-containing immune complexes initiates a number of leukocyte effector responses including antibody-dependent cellular cytotoxicity, phagocytosis, production and release of proteolytic enzymes including matrix metalloproteinases, and generation of reactive oxygen and nitrogen intermediates [28]. Ensuing damage to the alveolar walls and pulmonary interstitium could lead to fibroblast activation and aberrant deposition of fibrotic tissue which is characteristic of IPF. Accelerated pulmonary damage and fibrosis would result in more severe disease pathology and progression, as evidenced by more severe lung restriction (reduced $\mathrm{FEV}_{1}$ and FVC) and reduced gas transfer $\left(\mathrm{DL}_{\mathrm{CO}}\right)$, which in the present study are associated with the $\mathrm{H} 131$ allele.

Although the ancestral allele for the $\mathrm{R} 131 \mathrm{H}$ polymorphism is the $\mathrm{H}$ allele, in the present study the $\mathrm{R}$ allele was more prevalent than the $H$ allele. Since the H131 allele represents the sole human leukocyte Fc receptor allotype capable of binding to IgG2 it might have been subject to strong evolutionary forces which shaped $\mathrm{R} 131 \mathrm{H}$ genotype distribution in order to confer protection from a number of autoimmune and chronic inflammatory disorders. This assumption is strengthened by the fact that the frequency of the $\mathrm{R} 131 \mathrm{H}$ genotypes varies greatly between different ethnic groups, especially Caucasians and Asians, suggesting the presence of different evolutionary forces in different populations $[29,30]$. It should be noted that the genotype frequencies observed in this study are in accordance with those reported in several previously published studies in Caucasian populations [29,31].

Previous studies provide evidence for a role for immune complexes in IPF disease pathogenesis, either through initiation of local inflammatory responses or direct mediation of lung injury [3,7-12,14-16,32]. Further evidence for a role of immune complexes in IPF pathogenesis is provided by the association of IPF susceptibility with polymorphisms in the complement receptor 1 (CD35) gene that is involved in the clearance of circulating immune 
complexes [33]; however, additional studies failed to confirm such association in other ethnic groups [34,35]. IgG-mediated production and release of proinflammatory cytokines by Fc $\gamma$ RIIa-expressing leukocytes could amplify local inflammatory responses, leading to increased leukocyte infiltration [28]. A number of pro-inflammatory cytokines have been detected in the BAL fluid of IPF patients, including IL-1 $\beta$, IL-4, IL-8, IL-13, TNF- $\alpha$, TGF- $\beta$. Elicitation of the production of key fibrogenic molecules would accelerate fibrosis and disease progression [36-39]. Several reports describe associations of IPF with genes involved in proinflammatory pathways, including cytokines, chemokines and their corresponding receptors, and genes involved in tissue repair and fibrogenesis [40-49].

\section{Conclusions}

In summary, we have here reported that the Fc $\gamma$ RIIa $\mathrm{R} 131 \mathrm{H}$ polymorphism is associated with IPF severity and progression, providing additional support for the role of immunological mechanisms in the development of IPF. This not only supports existing evidence on the pathogenic potential of immune complexes, but also reveals a novel role of Fc $\gamma$ receptors in IPF disease progression. Given the relatively small size of the IPF cohort investigated here, additional studies on other IPF patients and different ethnic populations should be undertaken to further strengthen the observed association. Collectively, our results along with previous genetic association studies on IPF suggest that multiple genetic factors in combination with other environmental and immunological triggers can influence predisposition as well as disease progression. Identification of genetic variants that affect susceptibility or progression of IPF by altering the activity of molecules involved in inflammatory and pro-fibrotic pathways provides novel insights into the precise pathogenic mechanisms underlying IPF.

\footnotetext{
Acknowledgements

The authors wish to thank Dr. Andrew Robson (Pulmonary Function Department, Royal Infirmary of Edinburgh, UK) for his help in obtaining lung function measurements and Dr. Zhe Hui Hoo (Respiratory Medicine Unit, Royal Infirmary of Edinburgh, UK) for his help and comments. We are also grateful to Drs. Emma Cole, Stephen Maggs, Keith Hodgson and all the past members from our group (MRC Centre for Inflammation Research, UK) for their help and all the subjects, who participated in this study. This study was supported by the British Heart Foundation (FS/05/119/19568) and the Medical Research Council.

\section{Author details}

${ }^{1}$ University of Edinburgh/Medical Research Council Centre for Inflammation Research, Queen's Medical Research Institute, Edinburgh, UK. ${ }^{2}$ Centre for Cardiovascular Science, University of Edinburgh, Queen's Medical Research Institute, Edinburgh, UK. ${ }^{3}$ Department of Radiology, Royal Infirmary of Edinburgh, Edinburgh, UK. ${ }^{4}$ Department of Pathology, Royal Infirmary of Edinburgh, Edinburgh, UK. ${ }^{5}$ Respiratory Medicine Unit, Royal Infirmary of Edinburgh, Edinburgh, UK. ${ }^{6}$ Division of Cardiovascular and Respiratory Studies, Hull York Medical School/University of Hull, Castle Hill Hospital, Cottingham, UK
}

\section{Authors' contributions}

SB participated in study design, performed DNA extraction and genotyping analyzed genotypes and pulmonary function data, and drafted the manuscript; JG recruited patients and participated in DNA extraction and genotype determination; KMA developed and optimized the allele-specific PCR assay; JTM analyzed radiological data and established diagnosis; WAW performed histopathologic analysis and established diagnosis; PMcF recruited study subjects, collected blood samples, and kept records of diagnostic data; $\mathrm{NH}$ and AJS recruited IPF patients, established diagnosis, and obtained pulmonary function data; ID provided intellectual input, designed the study and drafted the manuscript; SPH designed and supervised the study, recruited subjects and established diagnosis, provided intellectual input and drafted the manuscript. All authors read and approved the final manuscript.

\section{Competing interests}

The authors declare that they have no competing interests.

Received: 23 June 2010 Accepted: 7 October 2010

Published: 7 October 2010

\section{References}

1. Flaherty KR, Travis WD, Colby TV, Toews GB, Kazerooni EA, Gross BH, Jain A, Strawderman RL, Flint A, Lynch JP, et al: Histopathologic variability in usual and nonspecific interstitial pneumonias. Am J Respir Crit Care Med 2001, 164(9):1722-1727.

2. Bradley B, Branley HM, Egan JJ, Greaves MS, Hansell DM, Harrison NK, Hirani N, Hubbard R, Lake F, Millar AB, et al: Interstitial lung disease guideline: the British Thoracic Society in collaboration with the Thoracic Society of Australia and New Zealand and the Irish Thoracic Society. Thorax 2008, 63(Suppl 5):v1-58

3. Ward PA: Immune complex injury of the lung. Am J Pathol 1979, 97(1):85-92.

4. Bódi I, Váradi P, Pokorny G, Engelhardt J, Dibó G, Vécsei L, Miko TL: Polyneuropathy with endoneurial immune complex deposition as the first manifestation of systemic lupus erythematosus. Acta Neuropathol 1998, 96(3):297-300

5. Digeon M, Droz D, Noel LH, Riza J, Rieumailhol C, Bach JF, Santoro F, Capron A: The role of circulating immune complexes in the glomerular disease of experimental hepatosplenic schistosomiasis. Clin Exp Immunol 1979, 35(3):329-337.

6. Tarzi RM, Cook HT: Role of Fcy receptors in glomerulonephritis. Nephron Exp Nephrol 2003, 95(1):e7-12.

7. Bellon B, Bernaudin JF, Mandet C, Chamak B, Kuhn J, Druet P: Immune complex-mediated lung injury produced by horseradish peroxidase (HRP) and anti-HRP antibodies in rats. Am J Pathol 1982, 107(1):16-24.

8. Dall'Aglio PP, Pesci A, Bertorelli G, Brianti E, Scarpa S: Study of immune complexes in bronchoalveolar lavage fluids. Respiration 1988, 54(Suppl 1):36-41

9. Dreisin RB, Schwarz MI, Theofilopoulos AN, Stanford RE: Circulating immune complexes in the idiopathic interstitial pneumonias. N Engl $J$ Med 1978, 298(7):353-357.

10. Gelb AF, Dreisen RB, Epstein JD, Silverthorne JD, Bickel $Y$, Fields $M$, Border WA, Taylor CR: Immune complexes, gallium lung scans, and bronchoalveolar lavage in idiopathic interstitial pneumonitis-fibrosis. Chest 1983, 84(2):148-153.

11. Haslam PL, Thompson B, Mohammed I, Townsend PJ, Hodson ME, Holborow EJ, Turner-Warwick M: Circulating immune complexes in patients with cryptogenic fibrosing alveolitis. Clin Exp Immunol 1979, 37(3):381-390.

12. Martinet $Y$, Haslam PL, Turner-Warwick M: Clinical significance of circulating immune complexes in 'lone' cryptogenic fibrosing alveolitis and those with associated connective tissue disorders. Clin Allergy 1984 14(5):491-497.

13. Gadek J, Hunninghake G, Zimmerman R, Kelman J, Fulmer J, Crystal RG: Pathogenetic studies in idiopathic pulmonary fibrosis. Control of neutrophil migration by immune complexes. Chest 1979, 75(2 Suppl):264-265.

14. Dobashi N, Fujita J, Murota M, Ohtsuki Y, Yamadori I, Yoshinouchi T, Ueda R, Bandoh S, Kamei T, Nishioka M, et al: Elevation of anti-cytokeratin 18 antibody and circulating cytokeratin 18: anti-cytokeratin 18 antibody 
immune complexes in sera of patients with idiopathic pulmonary fibrosis. Lung 2000, 178(3):171-179.

15. Takahashi T, Wada I, Ohtsuka Y, Munakata M, Homma Y, Kuroki Y: Autoantibody to alanyl-tRNA synthetase in patients with idiopathic pulmonary fibrosis. Respirology 2007, 12(5):642-653.

16. Wallace WA, Roberts SN, Caldwell H, Thornton E, Greening AP, Lamb D, Howie SE: Circulating antibodies to lung protein(s) in patients with cryptogenic fibrosing alveolitis. Thorax 1994, 49(3):218-224.

17. Bournazos S, Woof JM, Hart SP, Dransfield I: Functional and clinical consequences of $\mathrm{Fc}$ receptor polymorphic and copy number variants. Clin Exp Immunol 2009, 157(2):244-254.

18. Warmerdam PA, van de Winkel JG, Gosselin EJ, Capel PJ: Molecular basis for a polymorphism of human Fc $\gamma$ receptor II (CD32). J Exp Med 1990, 172(1):19-25.

19. American Thoracic Society, European Respiratory Society: American Thoracic Society/European Respiratory Society International Multidisciplinary Consensus Classification of the Idiopathic Interstitial Pneumonias. Am J Respir Crit Care Med 2002, 165(2):277-304.

20. Flaherty KR, Mumford JA, Murray S, Kazerooni EA, Gross BH, Colby TV, Travis WD, Flint A, Toews GB, Lynch JP, et al: Prognostic implications of physiologic and radiographic changes in idiopathic interstitial pneumonia. Am J Respir Crit Care Med 2003, 168(5):543-548.

21. Latsi PI, du Bois RM, Nicholson AG, Colby TV, Bisirtzoglou D, Nikolakopoulou A, Veeraraghavan S, Hansell DM, Wells AU: Fibrotic idiopathic interstitial pneumonia: the prognostic value of longitudinal functional trends. Am J Respir Crit Care Med 2003, 168(5):531-537.

22. Hanson D, Winterbauer RH, Kirtland SH, Wu R: Changes in pulmonary function test results after 1 year of therapy as predictors of survival in patients with idiopathic pulmonary fibrosis. Chest 1995, 108(2):305-310.

23. Wilson MS, Wynn TA: Pulmonary fibrosis: pathogenesis, etiology and regulation. Mucosal immunology 2009, 2(2):103-121.

24. Karassa FB, Trikalinos TA, Ioannidis JPA, Investigators F-SM-A: Role of the Fcy receptor lla polymorphism in susceptibility to systemic lupus erythematosus and lupus nephritis: a meta-analysis. Arthritis Rheum 2002, 46(6):1563-1571.

25. Yamamoto K, Kobayashi T, Grossi S, Ho AW, Genco RJ, Yoshie H, De Nardin E: Association of Fcy receptor lla genotype with chronic periodontitis in Caucasians. J Periodontol 2004, 75(4):517-522.

26. Wolf DL, Neiderud AM, Hinckley K, Dahlén G, van de Winkel JGJ, Papapanou PN: Fcy receptor polymorphisms and periodontal status: a prospective follow-up study. J Clin Periodontol 2006, 33(10):691-698.

27. van der Pol WL, van den Berg $L H$, Scheepers RH, van der Bom JG, van Doorn PA, van Koningsveld $\mathrm{R}$, van den Broek MC, Wokke JH, van de Winkel JG: IgG receptor Ila alleles determine susceptibility and severity of Guillain-Barré syndrome. Neurology 2000, 54(8):1661-1665.

28. Daëron M: Fc receptor biology. Annu Rev Immunol 1997, 15:203-234.

29. Botto M, Theodoridis E, Thompson EM, Beynon HL, Briggs D, Isenberg DA, Walport MJ, Davies KA: FcyRlla polymorphism in systemic lupus erythematosus (SLE): no association with disease. Clin Exp Immunol 1996, 104(2):264-268.

30. Chen J-Y, Wang C-M, Wu J-M, Ho H-H, Luo S-F: Association of rheumatoid factor production with FcyRllla polymorphism in Taiwanese rheumatoid arthritis. Clin Exp Immunol 2006, 144(1):10-16.

31. Salmon JE, Millard $S$, Schachter LA, Arnett FC, Ginzler EM, Gourley MF, Ramsey-Goldman R, Peterson MG, Kimberly RP: FcyRIIA alleles are heritable risk factors for lupus nephritis in African Americans. J Clin Invest 1996, 97(5):1348-1354

32. Dobashi N, Fujita J, Ohtsuki Y, Yamadori I, Yoshinouchi T, Kamei T, Tokuda M, Hojo S, Bandou S, Ueda Y, et al: Circulating cytokeratin 8:anticytokeratin 8 antibody immune complexes in sera of patients with pulmonary fibrosis. Respiration 2000, 67(4):397-401.

33. Zorzetto M, Ferrarotti I, Trisolini R, Agli LL, Scabini R, Novo M, De Silvestri A, Patelli M, Martinetti M, Cuccia M, et al: Complement receptor 1 gene polymorphisms are associated with idiopathic pulmonary fibrosis. Am $J$ Respir Crit Care Med 2003, 168(3):330-334.

34. Kubistova Z, Mrazek F, Lympany PA, Lagan AL, Arakelyan A, Kriegova E, Welsh KI, Kolek V, Zatloukal J, Hutyrova B, et al: The CR1 C5507G polymorphism is not involved in susceptibility to idiopathic pulmonary fibrosis in two European populations. Tissue Antigens 2008, 72(5):483-486.
35. Hodgson U, Tukiainen P, Laitinen T: The polymorphism C5507G of complement receptor 1 does not explain idiopathic pulmonary fibrosis among the Finns. Respir Med 2005, 99(3):265-267.

36. Agostini C, Gurrieri C: Chemokine/cytokine cocktail in idiopathic pulmonary fibrosis. Proc Am Thorac Soc 2006, 3(4):357-363.

37. Antoniou KM, Alexandrakis MG, Sfiridaki K, Tsiligianni I, Perisinakis $K$, Tzortzaki EG, Siafakas NM, Bouros DE: Th1 cytokine pattern (IL-12 and IL18) in bronchoalveolar lavage fluid (BALF) before and after treatment with interferon $\gamma$-1b (IFN- $\gamma-1 b)$ or colchicine in patients with idiopathic pulmonary fibrosis (IPF/UIP). Sarcoidosis, vasculitis, and diffuse lung diseases 2004, 21(2):105-110.

38. Standiford TJ, Rolfe MR, Kunkel SL, Lynch JP, Becker FS, Orringer MB, Phan S, Strieter RM: Altered production and regulation of monocyte chemoattractant protein-1 from pulmonary fibroblasts isolated from patients with idiopathic pulmonary fibrosis. Chest 1993, 103(2 Suppl):121S.

39. Zhang Y, Lee TC, Guillemin B, Yu MC, Rom WN: Enhanced IL-1 $\beta$ and tumor necrosis factor-a release and messenger RNA expression in macrophages from idiopathic pulmonary fibrosis or after asbestos exposure. J Immunol 1993, 150(9):4188-4196.

40. Checa M, Ruiz V, Montaño M, Velázquez-Cruz R, Selman M, Pardo A: MMP-1 polymorphisms and the risk of idiopathic pulmonary fibrosis. Hum Genet 2008, 124(5):465-472

41. Molina-Molina M, Xaubet A, Li X, Abdul-Hafez A, Friderici K, Jernigan $K$, Fu W, Ding Q, Pereda J, Serrano-Mollar A, et al: Angiotensinogen gene G$6 \mathrm{~A}$ polymorphism influences idiopathic pulmonary fibrosis disease progression. Eur Respir J 2008, 32(4):1004-1008.

42. Mushiroda T, Wattanapokayakit S, Takahashi A, Nukiwa T, Kudoh S, Ogura T, Taniguchi H, Kubo M, Kamatani N, Nakamura Y, et al: A genome-wide association study identifies an association of a common variant in TERT with susceptibility to idiopathic pulmonary fibrosis. J Med Genet 2008, 45(10):654-656.

43. Pantelidis P, Fanning GC, Wells AU, Welsh Kl, Du Bois RM: Analysis of tumor necrosis factor-a, lymphotoxin- $a$, tumor necrosis factor receptor II, and interleukin-6 polymorphisms in patients with idiopathic pulmonary fibrosis. Am J Respir Crit Care Med 2001, 163(6):1432-1436.

44. Riha RL, Yang IA, Rabnott GC, Tunnicliffe AM, Fong KM, Zimmerman PV: Cytokine gene polymorphisms in idiopathic pulmonary fibrosis. Intern Med J 2004, 34(3):126-129.

45. Selman $M$, Lin $H-M$, Montaño $M$, Jenkins $A L$, Estrada $A$, Lin Z, Wang $G$, DiAngelo SL, Guo X, Umstead TM, et al: Surfactant protein A and B genetic variants predispose to idiopathic pulmonary fibrosis. Hum Genet 2003, 113(6):542-550.

46. Vasakova M, Striz I, Dutka J, Slavcev A, Jandova S, Kolesar L, Sulc J: Cytokine gene polymorphisms and high-resolution-computed tomography score in idiopathic pulmonary fibrosis. Respir Med 2007, 101(5):944-950.

47. Whittington HA, Freeburn RW, Godinho SIH, Egan J, Haider Y, Millar AB: Analysis of an IL-10 polymorphism in idiopathic pulmonary fibrosis. Genes Immun 2003, 4(4):258-264.

48. Xaubet A, Marin-Arguedas A, Lario S, Ancochea J, Morell F, Ruiz-Manzano J, Rodriguez-Becerra E, Rodriguez-Arias JM, Inigo P, Sanz S, et al: Transforming growth factor- $\beta 1$ gene polymorphisms are associated with disease progression in idiopathic pulmonary fibrosis. Am J Respir Crit Care Med 2003, 168(4):431-435.

49. Whyte M, Hubbard R, Meliconi R, Whidborne M, Eaton V, Bingle C, Timms J, Duff G, Facchini A, Pacilli A, et al: Increased risk of fibrosing alveolitis associated with interleukin-1 receptor antagonist and tumor necrosis factor-a gene polymorphisms. Am J Respir Crit Care Med 2000, 162(2 Pt 1):755-758.

\section{Pre-publication history}

The pre-publication history for this paper can be accessed here: http://www.biomedcentral.com/1471-2466/10/51/prepub

doi:10.1186/1471-2466-10-51

Cite this article as: Bournazos et al:: Association of FcypRlla R131H polymorphism with idiopathic pulmonary fibrosis severity and progression. BMC Pulmonary Medicine 2010 10:51. 